\title{
TOWARD UNDERSTANDING THE RECENT LARGE REDUCTIONS IN U.S. ROAD FATALITIES
}

\author{
Michael SivaK \\ BRANDON SCHOETTLE
}

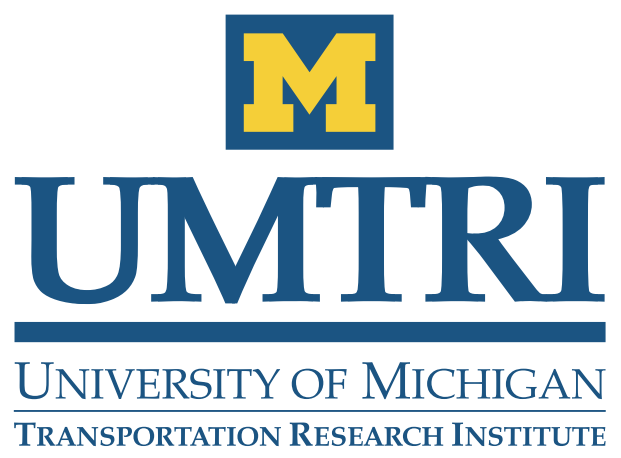


TOWARD UNDERSTANDING THE RECENT LARGE REDUCTIONS

IN U.S. ROAD FATALITIES

Michael Sivak

Brandon Schoettle

The University of Michigan

Transportation Research Institute

Ann Arbor, Michigan 48109-2150

U.S.A.

Report No. UMTRI-2010-12

May 2010 


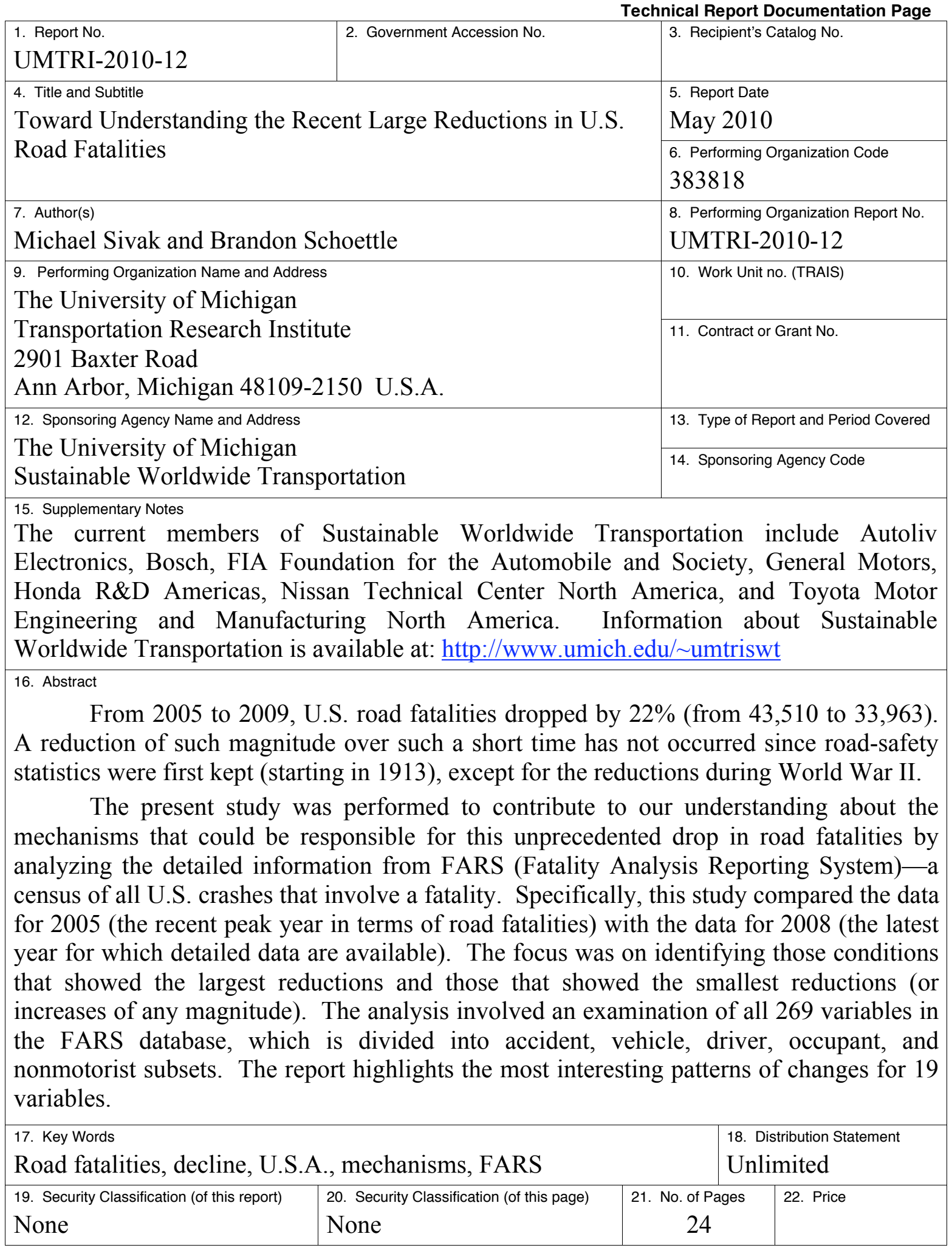




\section{Acknowledgment}

This research was supported by Sustainable Worldwide Transportation (http://www.umich.edu/ umtriswt). The current members of this research consortium are Autoliv Electronics, Bosch, FIA Foundation for the Automobile and Society, General Motors, Honda R\&D Americas, Nissan Technical Center North America, and Toyota Motor Engineering and Manufacturing North America.

We thank our colleague Charlie Compton for his assistance with the FARS database. 


\section{Contents}

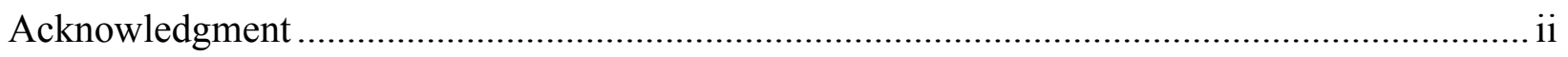

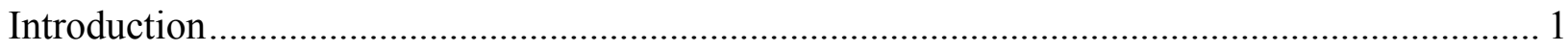

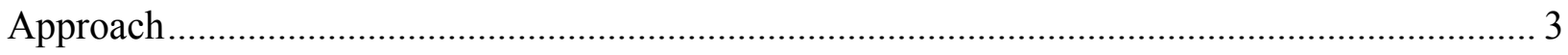

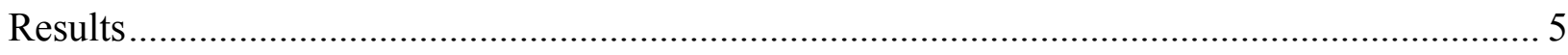

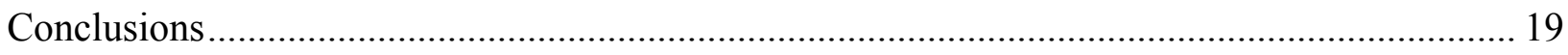

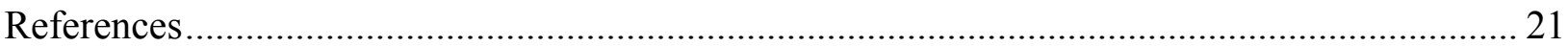




\section{Introduction}

From 1994 to 2005 , U.S. road fatalities increased by $7 \%$, from 40,716 to 43,510 . However, from 2005 to 2009, they dropped by 22\%, to 33,963 in 2009 (see Figure 1). A reduction of such magnitude over such a short time has not occurred since road-safety statistics were first kept (starting in 1913), except for the reductions during World War II (NSC, 2009).

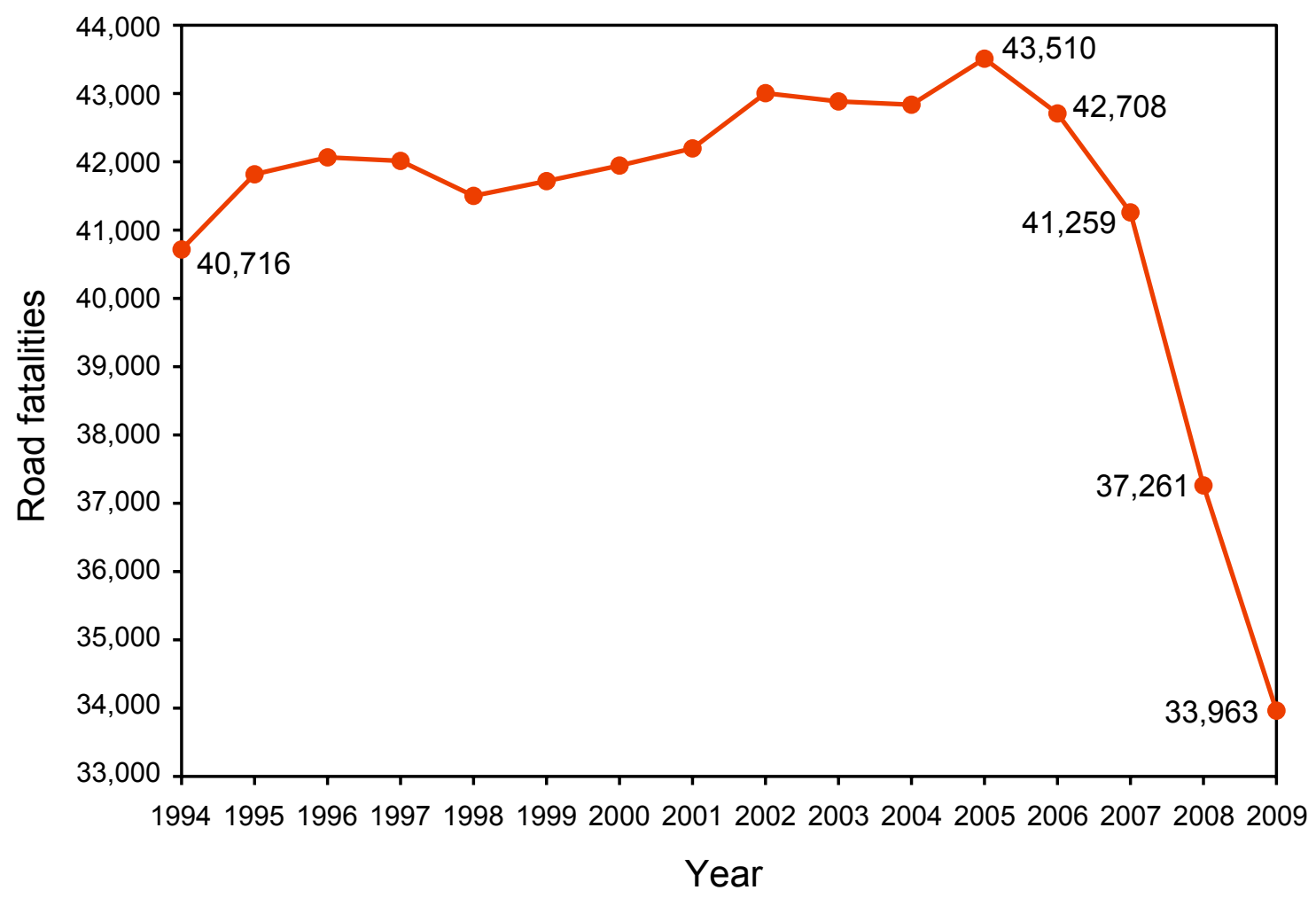

Figure 1. U.S. road fatalities from 1994 through 2009 (NHTSA, 2010a; 2010b).

What has caused this large reduction in road fatalities? In two previous publications, we began our examination of the factors associated with this reduction (Sivak, 2008; 2009), concentrating on the contribution of economic factors (e.g., the increase in the price of gasoline) and the resultant changes in driving amounts and patterns. At the time of the preparation of those two studies, detailed information about 
recent fatal crashes was not yet available. Therefore, those studies relied only on the total monthly fatality counts. The present study continues that examination of the possible mechanisms involved in the recent reductions in road fatalities by analyzing the detailed information from FARS (Fatality Analysis Reporting System) - a census of all U.S. crashes that involve a fatality. Specifically, this study compared the data for 2005 (the recent peak year in terms of fatalities) with the data for 2008 (the latest year for which detailed data are available). 


\section{Approach}

The approach involved comparing the distributions for each of the 269 variables in FARS for 2008 relative to those for 2005. The goal was to identify those conditions that showed the largest reductions and those that showed smallest reductions (or increases of any magnitude).

The FARS database is divided into five subsets that include variables related to

accidents, ${ }^{1}$ vehicles, drivers, occupants, and nonmotorists. For each variable, the changes for individual conditions from 2005 to 2008 were compared with the overall change for that subset. This approach is illustrated in Table 1, which shows the changes in the frequency of accidents by state. In 2005, there were 39,189 fatal accidents in the U.S. The corresponding number for 2008 was 34,017, for an overall reduction of $13.2 \%$. The entries in Table 1 include the states with the largest reductions in fatal accidents, and the states with the smallest reductions (or any increases). The changes for each state (the extremes being $-32.3 \%$ for South Dakota and $+3.8 \%$ for Utah) should be compared with the overall change for the entire U.S. (-13.2\%).

The appropriate comparison base (the overall reduction for the U.S.) varies based on the subset that the variable is from. The respective overall reductions were $13.2 \%$ for accidents, $15.1 \%$ for vehicles and drivers, $17.3 \%$ for occupants, and $10.1 \%$ for nonmotorists. The appropriate overall reduction for each variable is shown in each relevant table as the last entry (as are the corresponding yearly totals).

The tables in the Results section contain information concerning 18 variables, in addition to the state variable in Table 1, which led to interesting patterns of change. The tables for each of the selected variables highlight, in general, the variable values with the largest reductions from 2005 to 2008, and those with the smallest reductions (or any increases). However, certain extreme entries are not included, primarily because of small frequencies in the corresponding cells.

\footnotetext{
1 The currently preferred term is "crashes." However, the FARS database uses the term "accidents." Consequently, when referring to the FARS data, we retain the term "accidents."
} 
Table 1

Changes in fatal accidents for selected states.

\begin{tabular}{|r|r|l|c|}
\hline \multicolumn{2}{|c|}{ Year } & \multirow{2}{*}{ State } & $\begin{array}{c}\text { Change } \\
\text { from } 2005 \\
\text { to } 2008\end{array}$ \\
\cline { 1 - 2 } 2005 & 2008 & & $+3.8 \%$ \\
\hline \hline 235 & 244 & Utah & $-2.4 \%$ \\
\hline 3,104 & 3,031 & Texas & $-2.6 \%$ \\
\hline 347 & 338 & West Virginia & $-21.0 \%$ \\
\hline 238 & 188 & Nebraska & $-21.3 \%$ \\
\hline 80 & 63 & Rhode Island & $-21.4 \%$ \\
\hline 714 & 561 & Wisconsin & $-22.8 \%$ \\
\hline 1,230 & 950 & Illinois & $-22.9 \%$ \\
\hline 420 & 324 & New Mexico & $-24.4 \%$ \\
\hline 1,117 & 845 & Missouri & $-27.3 \%$ \\
\hline 44 & 32 & District of Columbia & $-32.3 \%$ \\
\hline 158 & 107 & South Dakota & $-13.2 \%$ \\
\hline 39,189 & 34,017 & Total accidents & \multicolumn{3}{|l}{} \\
\hline
\end{tabular}

To assess the potential influence on the overall fatalities, both the frequencies in the conditions of interest and the changes over time are important to consider. Therefore, Table 1 (and the tables that follow) presents not only the percentage changes from 2005 to 2008 but also the actual frequencies for both years. 


\section{Results}

Time of day

Fatal accidents during rush hours showed greater reductions than the overall accident reduction (Table 2). This finding is consistent with reduced commuter traffic because of the current economic downturn.

Table 2

Changes in fatal accidents by time of day.

\begin{tabular}{|c|c|c|c|}
\hline \multicolumn{2}{|c|}{ Year } & \multirow{2}{*}{ Time of day } & \multirow{2}{*}{$\begin{array}{l}\text { Change } \\
\text { from } 2005 \\
\text { to } 2008\end{array}$} \\
\hline 2005 & 2008 & & \\
\hline 4,998 & 4,486 & $12: 00 \mathrm{AM}-2: 59 \mathrm{AM}$ & $-10.2 \%$ \\
\hline 3,158 & 2,774 & 3:00 AM - 5:59 AM & $-12.2 \%$ \\
\hline 3,885 & 3,236 & 6:00 AM - 8:59 AM & $-16.7 \%$ \\
\hline 3,740 & 3,285 & 9:00 AM - 11:59 AM & $-12.2 \%$ \\
\hline 5,068 & 4,356 & 12:00 PM - 2:59 PM & $-14.0 \%$ \\
\hline 6,481 & 5,325 & 3:00 PM - 5:59 PM & $-17.8 \%$ \\
\hline 6,149 & 5,342 & 6:00 PM - 8:59 PM & $-13.1 \%$ \\
\hline 5,401 & 4,952 & 9:00 PM - 11:59 PM & $-8.3 \%$ \\
\hline 309 & 261 & Unknown & $-15.5 \%$ \\
\hline
\end{tabular}

\begin{tabular}{|l|l|l|l|}
\hline 39,189 & 34,017 & Total accidents & $-13.2 \%$ \\
\hline
\end{tabular}




\section{Roadway class}

Fatal accidents on rural interstates dropped substantially more than the overall accidents, while those on local roads/streets increased (Table 3). This pattern is consistent with a replacement of some long-distance leisure driving with local leisure driving in response to the economic concerns.

Table 3

Changes in fatal accidents for selected roadway classes.

\begin{tabular}{|c|c|c|c|}
\hline \multicolumn{2}{|c|}{ Year } & \multirow{2}{*}{ Roadway class } & \multirow{2}{*}{$\begin{array}{l}\text { Change } \\
\text { from } 2005 \\
\text { to } 2008\end{array}$} \\
\hline 2005 & 2008 & & \\
\hline \multicolumn{4}{|c|}{$R U R A L$} \\
\hline 3,937 & 3,848 & Principal arterial - other & $-2.3 \%$ \\
\hline 3,854 & 3,732 & Local road or street & $-3.2 \%$ \\
\hline 1,400 & 1,312 & Minor collector & $-6.3 \%$ \\
\hline 2,674 & 2,075 & Principal arterial - interstate & $-22.4 \%$ \\
\hline 21,010 & 18,762 & Total Rural & $-10.7 \%$ \\
\hline \multicolumn{4}{|c|}{$U R B A N$} \\
\hline 3,133 & 3,214 & Local road or street & $+2.6 \%$ \\
\hline 1,269 & 1,156 & Collector & $-8.9 \%$ \\
\hline 15,802 & 13,209 & Total urban & $-16.4 \%$ \\
\hline 39,189 & 34,017 & Total accidents & $-13.2 \%$ \\
\hline
\end{tabular}


Manner of collision, initial impact point, and airbag availability/deployment

Three related aspects were found. First, front-to-side fatal collisions (opposite direction or direction unknown) declined more than all fatal collisions (Table 4). Second, collisions with the initial impact point near 3 o'clock and 9 o'clock were reduced more than other collisions (Table 5). Third, airbag deployment from the side (or from an unknown direction) increased dramatically (Table 6), most likely reflecting the increased installation of side airbags. Consistent with this interpretation is the fact that the number of seats with no airbag protection was reduced more than the number of involved occupants (Table 6).

Front-to-front fatal collisions were also reduced more than all fatal collisions (Table 4). This could be a consequence of reduced speeds (see below), higher proportion of vehicles on the road with front airbags, and improved front airbags.

Table 4

Changes in fatal accidents for selected manners of collision.

\begin{tabular}{|c|c|c|c|}
\hline \multicolumn{2}{|c|}{ Year } & \multirow{2}{*}{ Manner of collision } & \multirow{2}{*}{$\begin{array}{l}\text { Change } \\
\text { from } 2005 \\
\text { to } 2008\end{array}$} \\
\hline 2005 & 2008 & & \\
\hline 23,181 & 21,102 & Not a collision with another motor vehicle & $-9.0 \%$ \\
\hline 2,414 & 2,113 & Front-to-rear (includes rear end) & $-12.5 \%$ \\
\hline 5,126 & 4,427 & Angle-front-to-side, right-angle & $-13.6 \%$ \\
\hline 506 & 423 & Angle-font-to-side, same direction & $-16.4 \%$ \\
\hline 4,010 & 3,219 & Front-to-front (includes head-on) & $-19.7 \%$ \\
\hline 2,279 & 1,567 & Angle-front-to-side, opposite direction & $-31.2 \%$ \\
\hline 298 & 141 & Angle-front-to-side, direction unknown & $-52.7 \%$ \\
\hline
\end{tabular}

\begin{tabular}{|l|l|l|l|}
\hline 39,189 & 34,017 & Total accidents & $-13.2 \%$ \\
\hline
\end{tabular}


Table 5

Changes in the initial impact point on the vehicles involved in fatal accidents.

\begin{tabular}{|c|c|c|c|}
\hline \multicolumn{2}{|c|}{ Year } & \multirow{2}{*}{ Initial impact point } & \multirow{2}{*}{$\begin{array}{l}\text { Change } \\
\text { from } 2005 \\
\text { to } 2008\end{array}$} \\
\hline 2005 & 2008 & & \\
\hline 3,088 & 2,477 & Noncollision & $-19.8 \%$ \\
\hline 37,194 & 32,049 & 11 to 1 o'clock & $-13.8 \%$ \\
\hline 5,416 & 4,576 & 2 to 4 o'clock & $-15.5 \%$ \\
\hline 4,284 & 3,791 & 5 to 7 o'clock & $-11.5 \%$ \\
\hline 6,390 & 4,964 & 8 to 10 o'clock & $-22.3 \%$ \\
\hline 447 & 393 & Top & $-12.1 \%$ \\
\hline 966 & 928 & Undercarriage & $-3.9 \%$ \\
\hline
\end{tabular}

\begin{tabular}{|r|r|l|l|}
\hline 1,588 & 1,252 & Other/Unknown & $-21.2 \%$ \\
\hline
\end{tabular}

\begin{tabular}{|l|l|l|l|}
\hline 59,373 & 50,430 & Total vehicles & $-15.1 \%$ \\
\hline
\end{tabular}

Table 6

Changes in selected conditions of airbag availability and/or deployment.

\begin{tabular}{|c|c|c|c|}
\hline \multicolumn{2}{|c|}{ Year } & \multirow{2}{*}{ Airbag availability/deployment } & \multirow{2}{*}{$\begin{array}{l}\text { Change } \\
\text { from } 2005 \\
\text { to } 2008\end{array}$} \\
\hline 2005 & 2008 & & \\
\hline 159 & 509 & Deployed from the side & $+220.1 \%$ \\
\hline 962 & 2,088 & Deployed from unknown direction & $+117.0 \%$ \\
\hline 735 & 1,052 & Deployed from multiple directions & $+43.1 \%$ \\
\hline 21,183 & 18,421 & Deployed from the front & $-13.0 \%$ \\
\hline 45,271 & 31,995 & Not available (for this seat) & $-29.3 \%$ \\
\hline 94,405 & 78,066 & Total occupants & $-17.3 \%$ \\
\hline
\end{tabular}


Speed limit and crash avoidance maneuver

Roads with a speed limit of $50 \mathrm{mph}$ or higher showed reductions that were greater than the overall reductions, while the opposite was the case for roads with speed limits between 20 and $45 \mathrm{mph}$ (Table 7). (Roads with speed limits between 5 and $15 \mathrm{mph}$ showed a large increase, but the actual frequencies are small.) This pattern is consistent with the postulated decrease in speeds as a consequence of drivers' efforts to improve the fuel economy of their vehicles (Sivak, 2008). (However, we were unable to find any quantitative data on changes in actual speeds.)

Supporting the reduction-in-speed hypothesis are the data on crash avoidance maneuvers (Table 8). Specifically, there was a disproportionate reduction in cases where no avoidance maneuver was reported. (The slower the speed, the more likely an avoidance maneuver is possible.)

Table 7

Changes in fatal accidents by posted speed limit.

\begin{tabular}{|r|r|l|c|}
\hline \multicolumn{2}{|c|}{ Year } & \multirow{2}{*}{ Speed limit } & $\begin{array}{c}\text { Change } \\
\text { from } 2005 \\
\text { to } 2008\end{array}$ \\
\hline 2005 & 2008 & & $+5.0 \%$ \\
\hline 120 & 126 & No statutory limit & $+35.3 \%$ \\
\hline 68 & 92 & $5-15 \mathrm{mph}$ & $-6.2 \%$ \\
\hline 3,852 & 3,613 & $20-30 \mathrm{mph}$ & $-11.4 \%$ \\
\hline 12,484 & 11,056 & $35-45 \mathrm{mph}$ & $-15.9 \%$ \\
\hline 14,887 & 12,524 & $50-60 \mathrm{mph}$ & $-15.5 \%$ \\
\hline 6,724 & 5,697 & $60+\mathrm{mph}$ & $-13.8 \%$ \\
\hline \multicolumn{3}{|c|}{} \\
\hline 1,053 & 908 & Unknown & $-13.2 \%$ \\
\hline 3
\end{tabular}


Table 8

Changes in crash avoidance maneuvers for drivers involved in fatal accidents.

\begin{tabular}{|r|r|l|c|}
\hline \multicolumn{2}{|c|}{ Year } & \multirow{2}{*}{ Crash avoidance maneuver } & $\begin{array}{c}\text { Change } \\
\text { from 2005 } \\
\text { to 2008 }\end{array}$ \\
\hline \hline 2005 & 2008 & & $+18.6 \%$ \\
\hline 2,598 & 2,177 & Steering and braking & $-16.2 \%$ \\
\hline 3,771 & 3,157 & Braking & $-16.3 \%$ \\
\hline 5,476 & 4,548 & Steering & $-16.9 \%$ \\
\hline 28,669 & 22,864 & No avoidance maneuver & $-20.2 \%$ \\
\hline
\end{tabular}

\begin{tabular}{|l|l|l|l|}
\hline 18,660 & 17,448 & Not reported (by police) & $-6.5 \%$ \\
\hline
\end{tabular}

\begin{tabular}{|l|l|l|l|}
\hline 59,373 & 50,430 & Total drivers & $-15.1 \%$ \\
\hline
\end{tabular}

\section{Construction zone}

Fatal accidents in construction zones decreased greatly (Table 9). This most likely reflects the fact that reduced highway budgets led to substantial reductions in road construction activities.

Table 9

Changes in fatal accidents occurring in construction zones.

\begin{tabular}{|r|r|l|c|}
\hline \multicolumn{2}{|c|}{ Year } & \multirow{2}{*}{ Construction zone } & $\begin{array}{c}\text { Change } \\
\text { from 2005 } \\
\text { to } 2008\end{array}$ \\
\hline 2005 & 2008 & & $-12.8 \%$ \\
\hline \hline 38,240 & 33,355 & None & $-30.2 \%$ \\
\hline 949 & 662 & Construction/maintenance/utility & $-13.2 \%$ \\
\hline
\end{tabular}


Number of fatalities per accident and number of fatalities per vehicle

Accidents with multiple fatalities were reduced more than those with a single fatality (Table 10). The same pattern is also evident in terms of the number of fatalities per vehicle (Table 11). These findings are consistent with the above-discussed increase in the availability and deployment of airbags.

Table 10

Changes in the total number of fatalities per accident.

\begin{tabular}{|c|c|c|c|}
\hline \multicolumn{2}{|c|}{ Year } & \multirow{2}{*}{ Number of fatalities per accident } & \multirow{2}{*}{$\begin{array}{l}\text { Change } \\
\text { from } 2005 \\
\text { to } 2008\end{array}$} \\
\hline 2005 & 2008 & & \\
\hline 35,803 & 31,376 & 1 fatality & $-12.4 \%$ \\
\hline 2,784 & 2,219 & 2 fatalities & $-20.3 \%$ \\
\hline 415 & 311 & 3 fatalities & $-25.1 \%$ \\
\hline 187 & 111 & 4 or more fatalities & $-40.6 \%$ \\
\hline
\end{tabular}

\begin{tabular}{|l|l|l|l|}
\hline 39,189 & 34,017 & Total accidents & $-13.2 \%$ \\
\hline
\end{tabular}

Table 11

Changes in the total number of fatalities per vehicle.

\begin{tabular}{|r|r|l|c|}
\hline \multicolumn{2}{|c|}{ Year } & \multirow{2}{*}{ Number of fatalities per vehicle } & $\begin{array}{c}\text { Change } \\
\text { from 2005 } \\
\text { to 2008 }\end{array}$ \\
\hline \hline 2005 & 2008 & & $-16.4 \%$ \\
\hline 31,417 & 27,212 & 1 fatality & $-13.4 \%$ \\
\hline 2,311 & 1,848 & 2 fatalities & $-20.0 \%$ \\
\hline 339 & 230 & 3 fatalities & $-32.2 \%$ \\
\hline 121 & 81 & 4 or more fatalities & $-33.1 \%$ \\
\hline
\end{tabular}

\begin{tabular}{|l|l|l|l|}
\hline 59,373 & 50,430 & Total vehicles & $-15.1 \%$ \\
\hline
\end{tabular}




\section{Vehicle body type}

The number of minivans, hatchbacks, 2-door vehicles, and utility station wagons in fatal crashes was reduced more than the overall vehicle reduction (Table 12), presumably reflecting the reduced frequency of these particular vehicles on the road. On the other hand, the involvement of motorcycles increased. This finding would be consistent with continuations of (1) an increase in motorcycle ownership by middle-aged men with little or no prior experience and (2) an increase sale of motorcycles with larger engine sizes - the trends noted by Shankar and Varghese (2006).

Table 12

Changes in fatalities for selected vehicle body types.

\begin{tabular}{|r|r|l|c|}
\hline \multicolumn{2}{|c|}{ Year } & \multirow{2}{*}{ Vehicle body type } & $\begin{array}{c}\text { Change } \\
\text { from 2005 } \\
\text { to } 2008\end{array}$ \\
\hline \hline 2005 & \multicolumn{1}{|c|}{2008} & & $+14.2 \%$ \\
\hline 4,492 & 5,129 & Motorcycle & $-15.2 \%$ \\
\hline 16,932 & 14,355 & 4 door sedan/hard top & $-23.6 \%$ \\
\hline 1,111 & 794 & 3 door/2 door hatchback & $-28.5 \%$ \\
\hline 5,055 & 3,359 & 2 door sedan/hard top/coupe & $-33.6 \%$ \\
\hline 464 & 264 & Utility station wagon & $-43.1 \%$ \\
\hline
\end{tabular}

\begin{tabular}{|l|l|l|l|}
\hline 59,373 & 50,430 & Total vehicles & $-15.1 \%$ \\
\hline
\end{tabular}


VIN truck weight code

The involvement of heavy trucks was reduced more than the involvement of all vehicles (Table 13). This is consistent with the overall reduction in freight shipments due to the economic downturn (BTS, 2010).

\section{Table 13}

Changes in selected categories of weights for vehicles involved in fatal accidents.

\begin{tabular}{|r|c|l|c|}
\hline \multicolumn{2}{|c|}{ Year } & \multirow{2}{*}{ VIN truck weight code } & $\begin{array}{c}\text { Change } \\
\text { from } 2005 \\
\text { to } 2008\end{array}$ \\
\hline \hline 1,562 & 1,251 & $10,001-33,000$ lbs. & $-19.9 \%$ \\
\hline 3,780 & 3,081 & 33,001 or more lbs. & $-18.5 \%$ \\
\hline 59,373 & 50,430 & Total vehicles & $-15.1 \%$ \\
\hline
\end{tabular}


Driver drinking and previous DWI (driving while intoxicated) convictions

As shown in Table 14, the number of drivers with drinking reported showed a disproportionately small reduction. (Conversely, the number of drivers with no drinking reported showed a disproportionately large reduction.) This could be a reflection of the increased alcohol consumption per capita (of beer, wine, and distilled spirits) from 2005 to 2008 (USDA, 2010), or increased DWI enforcement leading to higher detection.

At the same time, the number of repeat DWI offenders showed a disproportionately large reduction (Table 15). This may be a consequence of a disproportionate decrease in driving by repeat DWI offenders due to economic factors, because drivers from lower socio-economic groups tend to be overrepresented among repeat DWI offenders (Jones and Lacey, 2000).

Table 14

Changes in reported drinking for drivers involved in fatal accidents.

\begin{tabular}{|c|c|c|c|}
\hline \multicolumn{2}{|c|}{ Year } & \multirow{2}{*}{ Driver drinking } & \multirow{2}{*}{$\begin{array}{l}\text { Change } \\
\text { from } 2005 \\
\text { to } 2008\end{array}$} \\
\hline 2005 & 2008 & & \\
\hline 11,783 & 11,015 & Drinking reported & $-6.5 \%$ \\
\hline 47,590 & 39,415 & No drinking reported & $-17.2 \%$ \\
\hline
\end{tabular}

\begin{tabular}{|l|l|l|l|}
\hline 59,373 & 50,430 & Total drivers & $-15.1 \%$ \\
\hline
\end{tabular}

Table 15

Changes in selected categories of previous DWI convictions for drivers involved in fatal accidents.

\begin{tabular}{|}
\begin{tabular}{|r|r|l|c|}
\hline \multicolumn{2}{|c|}{ Year } & Number of previous DWI convictions \\
per driver & $\begin{array}{c}\text { Change } \\
\text { from 2005 } \\
\text { to } 2008\end{array}$ \\
\hline \hline 54,917 & 46,865 & 0 DWI convictions & $-14.7 \%$ \\
\hline 1,477 & 1,222 & 1 DWI conviction & $-17.3 \%$ \\
\hline 208 & 157 & 2 DWI convictions & $-24.5 \%$ \\
\hline 59,373 & 50,430 & Total drivers & $-15.1 \%$ \\
\hline
\end{tabular}
\end{tabular}


Previous involvement in accidents

The number of drivers with two or more previous accidents was reduced more than the average reduction in the number of involved drivers (Table 16). Possible explanations include the above-discussed disproportionate reduction in driving by drivers with multiple prior DWI convictions, and a disproportionate reduction in driving by persons from lower socio-economic groups who tend to have worse driving records (Stamatiadis and Puccini, 1999).

Table 16

Changes in selected categories of previous accidents for drivers involved in fatal accidents.

\begin{tabular}{|c|c|c|c|}
\hline \multicolumn{2}{|c|}{ Year } & \multirow{2}{*}{$\begin{array}{c}\text { Number of previous accidents } \\
\text { per driver }\end{array}$} & \multirow{2}{*}{$\begin{array}{l}\text { Change } \\
\text { from } 2005 \\
\text { to } 2008\end{array}$} \\
\hline 2005 & 2008 & & \\
\hline 45,699 & 39,057 & 0 accidents & $-14.5 \%$ \\
\hline 6,112 & 5,239 & 1 accident & $-14.3 \%$ \\
\hline 1,070 & 795 & 2 accidents & $-25.7 \%$ \\
\hline 230 & 167 & 3 accidents & $-27.4 \%$ \\
\hline
\end{tabular}

\begin{tabular}{|l|l|l|l|}
\hline 59,373 & 50,430 & Total drivers & $-15.1 \%$ \\
\hline
\end{tabular}




\section{Driver-related factors ${ }^{2}$}

As shown in Table 17, among driver-related factors that exhibited unusually large reductions were operating the vehicle in an erratic, reckless, careless, or negligent manner (possibly due to decreased speeds), as well as being drowsy, sleepy, asleep, or fatigued (possibly due to a disproportionate reduction in long-distance leisure driving, which more frequently involves nighttime driving than commuter driving). On the other hand, inattentive driving (talking, eating, using cell phones, etc.) showed a large increase (possibly reflecting the increased pace and complexity of daily lives, increased distractions, or increased sensitivity of coders to the issue of distractions). (The data on road rage are based on small numbers.)

Table 17

Changes in selected driver-related factors for drivers involved in fatal accidents.

\begin{tabular}{|r|r|l|c|}
\hline \multicolumn{2}{|c|}{ Year } & \multicolumn{1}{c|}{ Driver related factors } & $\begin{array}{c}\text { Change } \\
\text { from } 2005 \\
\text { to } 2008\end{array}$ \\
\hline \hline 2005 & 2008 & & $+116.4 \%$ \\
\hline 489 & 909 & $\begin{array}{l}\text { Illegal driving on road shoulder, in ditch, on sidewalk } \\
\text { or on median }\end{array}$ & $+102.1 \%$ \\
\hline 2,369 & 3,366 & Inattentive (talking, eating, using cell phones, etc.) & $+42.1 \%$ \\
\hline 5,419 & 5,125 & Under the influence of alcohol, drugs or medication & $-5.4 \%$ \\
\hline 21,324 & 17,437 & None & $-18.2 \%$ \\
\hline 8,860 & 6,323 & Failure to keep in proper lane & $-28.6 \%$ \\
\hline 785 & 477 & Drowsy, sleepy, asleep, fatigued & $-39.2 \%$ \\
\hline 176 & 75 & Pedestrian, pedalcyclist, or other nonmotorist & $-57.4 \%$ \\
\hline 1,009 & 426 & $\begin{array}{l}\text { Operating the vehicle in an erratic, reckless, careless or } \\
\text { negligent manner }\end{array}$ & $-57.8 \%$ \\
\hline 59,373 & 50,430 & Total drivers & $-15.1 \%$ \\
\hline
\end{tabular}

\footnotetext{
${ }^{2}$ The FARS database contains four sets of driver-related factors. Here we report only on the first (primary) factor.
} 


\section{Driver age}

Drivers between 16 and 25 years of age showed a disproportionate decrease of involvement in fatal accidents (Table 18). Possible explanations include a disproportionate reduction in the amount of driving in this age group because young drivers are likely to be more affected by economic fluctuations, and the increased implementation of effective graduated driver licensing.

Table 18

Changes in the ages of drivers involved in fatal accidents.

\begin{tabular}{|r|r|l|c|}
\hline \multicolumn{2}{|c|}{ Year } & \multirow{2}{*}{ Driver age } & $\begin{array}{c}\text { Change } \\
\text { from } 2005 \\
\text { to } 2008\end{array}$ \\
\hline \hline 2005 & \multicolumn{1}{|r|}{2008} & & $-29.9 \%$ \\
\hline 7,293 & 5,729 & $16-20$ & $-21.4 \%$ \\
\hline 7,939 & 6,503 & $21-25$ & $-18.1 \%$ \\
\hline 11,084 & 9,402 & $26-35$ & $-15.2 \%$ \\
\hline 10,683 & 8,762 & $36-45$ & $-18.0 \%$ \\
\hline 9,147 & 8,154 & $46-55$ & $-10.9 \%$ \\
\hline 5,623 & 5,390 & $56-65$ & $-4.1 \%$ \\
\hline 3,082 & 2,749 & $66-75$ & $-10.8 \%$ \\
\hline 2,158 & 1,899 & $76-85$ & $-12.0 \%$ \\
\hline 602 & 537 & 86 or older & $-10.8 \%$ \\
\hline \multicolumn{3}{|c|}{} \\
\hline 1,458 & 1,092 & Unknown & $-25.1 \%$ \\
\hline
\end{tabular}

\begin{tabular}{|l|l|l|l|}
\hline 59,373 & 50,430 & Total drivers & $-15.1 \%$ \\
\hline
\end{tabular}




\section{Nonmotorist locations}

Table 19 indicates that there was an unusually large drop in pedestrian fatalities due to jaywalking (being on the roadway away from a designated pedestrian crossing). This would be consistent with the above-postulated general decrease in driving speeds, because slower speeds would make jaywalking less dangerous.

Table 19

Changes in selected categories of the locations relative to the roadway for nonmotorists involved in fatal accidents.

\begin{tabular}{|c|c|c|c|}
\hline \multicolumn{2}{|c|}{ Year } & \multirow{2}{*}{ Nonmotorist location } & \multirow{2}{*}{$\begin{array}{c}\text { Change } \\
\text { from } 2005 \\
\text { to } 2008\end{array}$} \\
\hline 2005 & 2008 & & \\
\hline 173 & 294 & Intersection - on roadway, crosswalk availability unknown & $+69.9 \%$ \\
\hline 187 & 222 & Intersection - on roadway, crosswalk not available & $+18.7 \%$ \\
\hline 1,941 & 2,065 & Nonintersection - on roadway, crosswalk not available & $+6.4 \%$ \\
\hline 462 & 487 & Intersection - in crosswalk & $+5.4 \%$ \\
\hline 434 & 378 & Intersection - on roadway, not in crosswalk & $-12.9 \%$ \\
\hline 1,701 & 1,002 & Nonintersection - on roadway, not in crosswalk & $-41.1 \%$ \\
\hline 6,629 & 5,960 & Total nonmotorists & $-10.1 \%$ \\
\hline
\end{tabular}




\section{Conclusions}

This study examined the changes in the characteristics of U.S. fatal crashes from 2005 (the recent peak year in terms of fatalities) to 2008 (the latest year for which

detailed data are available). The main findings, and possible explanations, are summarized in Table 20. 
Table 20

Summary of the main findings.

Desirable changes are in green and undesirable changes are in red.

\begin{tabular}{|c|c|c|}
\hline Aspect & $\begin{array}{l}\text { Change from } 2005 \\
\text { to } 2008 \text { relative to } \\
\text { the average change }\end{array}$ & Possible explanation(s) \\
\hline Rush hours & Down & Decreased commuter travel \\
\hline Interstates & Down & Reduced long-distance leisure travel \\
\hline Local roads/streets & Up & Increased local leisure travel \\
\hline Side crashes & Down & More side airbags \\
\hline $\begin{array}{l}\text { Deployment of side } \\
\text { airbags }\end{array}$ & Up & More side airbags \\
\hline Seats with no airbags & Down & More airbags \\
\hline Frontal crashes & Down & $\begin{array}{l}\text { Decreased speeds; more seats with front } \\
\text { airbags; improved airbags }\end{array}$ \\
\hline $\begin{array}{l}\text { Roads with higher } \\
\text { speed limits }\end{array}$ & Down & Decreased speeds \\
\hline No avoidance maneuver & Down & Decreased speeds \\
\hline Construction zone & Down & Reduced road construction \\
\hline $\begin{array}{l}\text { Multiple fatalities per } \\
\text { crash and per vehicle }\end{array}$ & Down & More airbags \\
\hline Motorcycles & $\mathrm{Up}$ & $\begin{array}{l}\text { Increased ownership (1) by middle-aged } \\
\text { men and ( } 2 \text { ) of larger motorcycles }\end{array}$ \\
\hline Heavy trucks & Down & Reduced freight shipments \\
\hline Reported alcohol use & Up & $\begin{array}{l}\text { Increased alcohol consumption; } \\
\text { increased DWI enforcement }\end{array}$ \\
\hline Repeat DWI offenders & Down & $\begin{array}{l}\text { Disproportionate reduction in driving by } \\
\text { repeat DWI offenders }\end{array}$ \\
\hline $\begin{array}{l}\text { Repeat crash } \\
\text { involvement }\end{array}$ & Down & $\begin{array}{l}\text { Decreased alcohol involvement; fewer } \\
\text { high-risk drivers on the road }\end{array}$ \\
\hline Reckless driving & Down & Decreased speeds \\
\hline Drowsy driving & Down & $\begin{array}{l}\text { Disproportionate decrease in long- } \\
\text { distance leisure driving }\end{array}$ \\
\hline Inattentive driving & Up & $\begin{array}{l}\text { Increased complexity of daily lives; } \\
\text { increased distractions; increased coder } \\
\text { sensitivity to the issue of distractions }\end{array}$ \\
\hline Young drivers & Down & $\begin{array}{l}\text { Fewer young drivers on the road; } \\
\text { increased use of graduated licensing }\end{array}$ \\
\hline Jaywalking & Down & Decreased speeds \\
\hline
\end{tabular}




\section{References}

BTS [Bureau of Transportation Statistics]. (2010). Transportation Services Index. Available at http://www.bts.gov/xml/tsi/src/index.xml.

Jones, R.K. and Lacey, J.H. (2000). State of knowledge of alcohol-impaired driving: Research on repeat DWI offenders (Report No. DOT HS 809 027). Washington, D.C.: National Highway Traffic Safety Administration.

NHTSA [National Highway Traffic Safety Administration]. (2010a). Early estimate of motor vehicle traffic fatalities in 2009 (Report No. DOT HS 811 291). Washington, D.C.: Author.

NHTSA [National Highway Traffic Safety Administration]. (2010b). Fatality Analysis Reporting System. Available at http://www-fars.nhtsa.dot.gov.

NSC [National Safety Council]. (2009). Injury facts (2009 edition). Itasca, IL: Author.

Shankar, U. and Verghese, C. (2006). Recent trends in fatal motorcycle crashes: An update (Report No. DOT HS 810 606). Washington, D.C.: National Highway Traffic Safety Administration.

Sivak, M. (2008). Is the U.S. on the path to the lowest motor vehicle fatalities in decades? (Technical Report No. UMTRI-2008-39.) Ann Arbor: The University of Michigan Transportation Research Institute.

Sivak, M. (2009). Mechanisms involved in the recent large reductions in U.S. road fatalities. Injury Prevention, 15, 205-206.

Stamatiadis, N. and Puccini, G. (1999). Fatal crash rates in the Southeastern United States: Why are they higher? Transportation Research Record, 1665, 118-124.

USDA [U.S. Department of Agriculture]. (2010). U.S. per capita food availability: Beverages by individual beverage. Available at http://www.ers.usda.gov/Data/FoodConsumption/app/reports/displayCommoditie s.aspx? reportName $=$ Beverages $\% 20$ by $\% 20$ individual $\% 20$ beverage $\&$ id $=42 \#$ startFo rm. 